Суслов Микола,

ORCID ID 0000-0003-0595-237X

E-mail: $\underline{\text { Suslov20@ukr.net }}$

\title{
ЛОКАЛЬНА ІДЕНТИЧНІСТЬ ЯК ПРІОРИТЕТНИЙ НАПРЯМ У СТРАТЕГІЧНОМУ ПЛАНУВАННІ РОЗВИТКУ ТЕРИТОРІАЛЬНИХ ГРОМАД
}

\author{
https://doi.org/10.32689/2618-0065-2021-2(8)-133-151
}

\begin{abstract}
Анотація. Досліджено локальну ідентичність як пріоритетний напрям у стратегічному плануванні територіальних громад (ТГ) на сучасному етапі. Локальна ідентичність - це ототожнення себе із суспільством, яке проживає на даній території, зокрема на території ТГ. В умовах децентралізації локальна ідентифікація $є$ суттєвою опорою для членів місцевого співтовариства ТГ, що дозволяє їм визначити власне становище, й стає підставою активності у вирішенні місцевих справ. У формуванні локальної ідентичності ТГ автором виділено чотири основних компоненти: 1) локальний (територіальний) менталітет - властивий жителям певної місцевості, характерна для них система цінностей і оцінок; 2) уявлення про особливості й властивості території свого проживання; 3) територіальні інтереси - загальні для членів відповідної територіальної спільноти уявлення про стан, цілі і шляхи розвитку території; 4) локальна (просторова) самоідентифікація як усвідомлення приналежності до тієї території, територіальної спільності. Одним 3 найважливіших пріоритетів процесу децентралізації є створення фінансово спроможних громад, що передбачає зосередження уваги не тільки на кількості створених ТГ, але й на їх якості. Автором доведено, що базовим документом, що передбачає формування спроможної ТГ є стратегія розвитку громад. 3'ясовано, що основна проблема створення стратегічного плану полягає в тому, що він має формуватися при активній участі членів ТГ. Саме завдяки локальній ідентичності може забезпечуватися активна участь громадян у прийнятті рішень місцевого значення. У статті автор приходить до висновку, що стратегічне планування у розвитку ТГ повинне бути не лише інструментом економічно-соціальної ефективності та поліпшення життя громади, але і частиною політики формування локальної ідентичності, заснованої на принципах демократії, i повного урахування прав громадян.
\end{abstract}

Ключові слова: локальна ідентичність, децентралізація, спроможність, стратегічне планування ТГ. 


\section{Науковий вісник : державне управління № 2(8) 2021}

Постановка проблеми. У процесі децентралізації та створення спроможних територіальних громад (далі - ТГ) формується абсолютно нова територіальна спільнота, адже до іiі складу починають входити декілька громад. Саме тому актуальною проблемою стає процес інтегрування індивіда у нові відносини, що формуються, його ототожнення 3 певними цінностями, цілями ТГ. Відбувається процес ідентифікації індивідів, тобто почуття їх приналежності до місцевого співтовариства, якому децентралізація надає повноваження, ресурси та можливість впливати на розвиток (прогнозований та вмотивований), благополуччя населення. Децентралізація - це об'єктивна вимога часу з економічної точки зору вона є засобом згуртування громад, що увійшли до складу ТГ навколо нових цінностей $\mathrm{i}$ довгострокових перспектив. Децентралізація $€$ інструментом підвищення конкурентоспроможності ТГ тому, що дозволяє місцевому співтовариству планувати власний розвиток. Вважаємо, що майбутнє ТГ залежить від стратегічного планування iii розвитку, що неможливо без формування локальної ідентичності, яка є «важливим фактором консолідації територіальної громади, іiі «ціннісного» ядра i визначального фактору майбутнього розвитку» [1, с. 131].

Тут варто зауважити, що процес формування локальної ідентичності ТГ є досить непростим і потребує значних зусиль і ресурсів, зокрема у з'ясуванні іiі ролі у процесах стратегічного розвитку ТГ.

Аналіз останніх досліджень і публікацій. Використану у статті літературу можна класифікувати за територіальним критерієм: праці американських, європейських та вітчизняних науковців. Для даного дослідження великий інтерес становлять праці Е. Еріксона (1902-1994), відомого у всьому світі американсько-німецького психолога, соціолога, клініциста у галузі психоаналізу та розвитку людини, який запропонував термін «кризис ідентичності»; латвійських вчених Дж. Якайтіса та Г. Стаускіса, що вивчають місцеві територіальні громади у міській структурі м. Вільнюса; українських дослідників Я. Котенка, А. Ткачука, О. Свтушенка, Т. Лушагіної, В. Лоли, Л. Овчиннікової.

Я. Котенко та А. Ткачук досліджують зміст та структуру 
поняття «ідентичність»; аналізують локальну ідентичність у системі територіально-просторової ідентичності; демонструють інструменти та практики формування i конструювання локальної ідентичності [2].

Вітчизняні дослідники О. Свтушенко та Т. Лушагіна висловлюють думку, що: «...не менш важливе значення має місцева ідентичність. Місцева або територіальна ідентичність це «сприйняття індивідом себе як представника певної «уявленої спільноти», яка грунтується на єдності території проживання, історії та традицій, соціокультурного досвіду, ціннісних орієнтацій та способу життя. Вона може виникати 3 об'єктами різного масштабу та змісту. Це такими, як місце проживання, мікрорайон, район, локальна община, село, селище, місто, територіальна громада, регіон, країна, субконтинент, континент, або земна куля» [3, с. 404]. Але необхідно відмітити той факт, що міська ідентичність передбачає наявність більшої кількості спільних традицій серед жителів ТГ, аніж локальна.

У зв'язку з тим, що в умовах децентралізації локальна ідентичність ТГ стає первинним, базовим рівнем територіальнопросторової ідентичності вона «виступає своєрідним індикатором згуртованості громади, іiі активності, а значить i спроможності». Тому формування локальної ідентичності стає пріоритетом у стратегічному плануванні соціальноекономічного розвитку ТГ, реалізації культурних, освітніх, соціальних, спортивних проектів» [4, с. 2].

В. Лола приходить до висновку, що: «Включеність» (залучення) у мережу соціальних відносин та колективної взаємодії $є$ визначальним фактором формування громади як певного соціального організму, який функціонує на основі спільності інтересів, соціальної довіри та здатності до колективної дії. Важливою ознакою такої громади є наявність спільної ідентичності» [1, с. 135]. Л. Овчиннікова займається вивченням ролі локальної спільноти та місця як важливих факторів формування локальної ідентичності індивіда [5, c. 138].

Автор теорії ідентичності, психолог Е. Еріксон першим показав, що потреба людини в позитивній ідентичності часто 


\section{Науковий вісник : державне управління № 2(8) 2021}

реалізується «через негативні образи ... живе за рахунок приниження інших» [6, с. 121]. Значну роль під час написання статті відіграли роботи європейських фахівців. Слід згадати статтю Дж. Якайтіса та Г. Стаускіса [7, p. 913] у якій представлений аналіз загальних принципів ідентифікації місцевих ТГ у міській структурі сучасних міст та представлена методологія включення громадської ініціативи як сильного фактора планування міського розвитку. На прикладі міста Вільнюс у дослідженні представлений спосіб активізації груп місцевих жителів 3 основним акцентом на вдосконаленні стратегій розвитку міст та місцевої муніципальної політики, а також конкретних планів розвитку. Широкий спектр інтересів, які мають ТГ в районі свого проживання, дозволяє планувати розвиток найрізноманітніших міських систем за допомогою сформованої локальної ідентичності.

Отже, проблема співвідношення окремих типів ідентичностей, а також пошук пояснювальних механізмів їх формування і прояву - одна 3 центральних дискусій соціогуманітарного знання на сьогоднішній день. На думку автора, праці українських та зарубіжних вчених є досить важливими для розуміння локальної ідентичності як пріоритету у стратегічному плануванні ТГ на сучасному етапі. Актуальність даної проблеми підсилює й те, що у вітчизняній науці державного управління до теперішнього моменту немає узагальнюючих досліджень щодо значення локальної ідентичності як пріоритету у стратегічному плануванні розвитку ТГ.

Методи дослідження. Дослідження побудовано на основі застосування загальнонаукових методів пізнання, iз застосуванням науково-критичного аналізу джерел, методів загального (аналіз і синтез) та спеціального (системний) характеру.

Для одержання загального уявлення про локальну ідентичність широко використовується описовий аналіз. Важливим методологічним принципом виступає принщиип розвитку. Принцип розвитку орієнтує історичне пізнання, сходження від простих організаційних форм до більш складних. Прикладом такого розвитку може виступати еволюція 
локальної ідентичності у процесі створення спроможних ТГ. У статті використовувався принщип об'єктивності, котрий означає неупередженість, незалежність суджень дослідника, хоча при цьому він не повинен бути нейтральним і має право на обгрунтування власної позиції. За допомогою аналітичного методу з усього масиву доступної інформації автор виділяє основне, що має найбільш близьке відношення до теми. Застосування статистичного методу дозволило підтвердити деякі факти конкретними цифрами щодо проблеми. Поєднання зазначених принципів та методів дало можливість автору уникнути суб'єктивних оцінок і забезпечило наукову достовірність результатів дослідження.

Мета статті полягає у дослідженні локальної ідентичності як пріоритетного напряму у стратегічному плануванні ТГ на сучасному етапі.

Виклад основного матеріалу. Поняття «ідентичність» першочергово виникнуло в рамках психології особистості, i почало означати результат ідентифікації людини чи групи 3 будь-якою соціальною спільнотою, наприклад, етнічною. Людина володіє відразу декількома ідентичностями, в яких відображається іiі стать, етнічність, раса, релігійна приналежність, національна та інші сторони життя. Локальна ідентичність - це ототожнення себе із суспільством, яке проживає на даній території, зокрема на території ТГ.

Автор використовує термін «локальний» (від лат. locālis «місце», «конкретне місце») рівень, для позначення найменшої адміністративно-територіальної одиниці - територіальної громади, первинного суб'єкту місцевого самоврядування. Під терміном «ідентичність» (від лат. idem - «такий самий», «самосвідомість») ми розуміємо самоусвідомлення індивідом його належності до певного співтовариства. Таким чином, локальна ідентичність - це первинний, базовий рівень територіально-просторової ідентичності, системна сукупність культурних, історичних, економічних, соціальних відносин, яка формується на основі місця проживання та $\epsilon$ фактором самоототожнення індивідів як членів місцевого співтовариства, тобто ТГ.

Дослідження локальної ідентичності в умовах 
децентралізації й створення спроможних $T \Gamma$ в Україні, представляється досить актуальним i, таким, що має безсумнівний науково-практичний інтерес. По-перше, тому, що розвиток ТГ залежить від саморозвитку місцевого співтовариства на базі якого формується ТГ, ідентифікації місцевих індивідів їх самоототожнення 3 іншими членами громади; по-друге, згуртоване місцеве співтовариство - це створення локального територіального простору, в якому місцеві мешканці існують, керуються певними традиціями й цінностями, формують відповідні комунікації в процесі взаємовідносин й планують своє власне майбутнє; по-третє, в сучасних умовах ТГ є первинним осередком суспільства, для якого характерне виникнення основних соціально-політичних i економічних відносин. Ознаками ТГ є: 1) спільна територія проживання; 2) спільні інтереси у вирішенні питань життєдіяльності; 3) соціальна взаємодія під час реалізації цих інтересів; 4) самоідентифікація кожного члена з громадою i, як наслідок - виникнення своєї локальної ідентичності [2, с. 33].

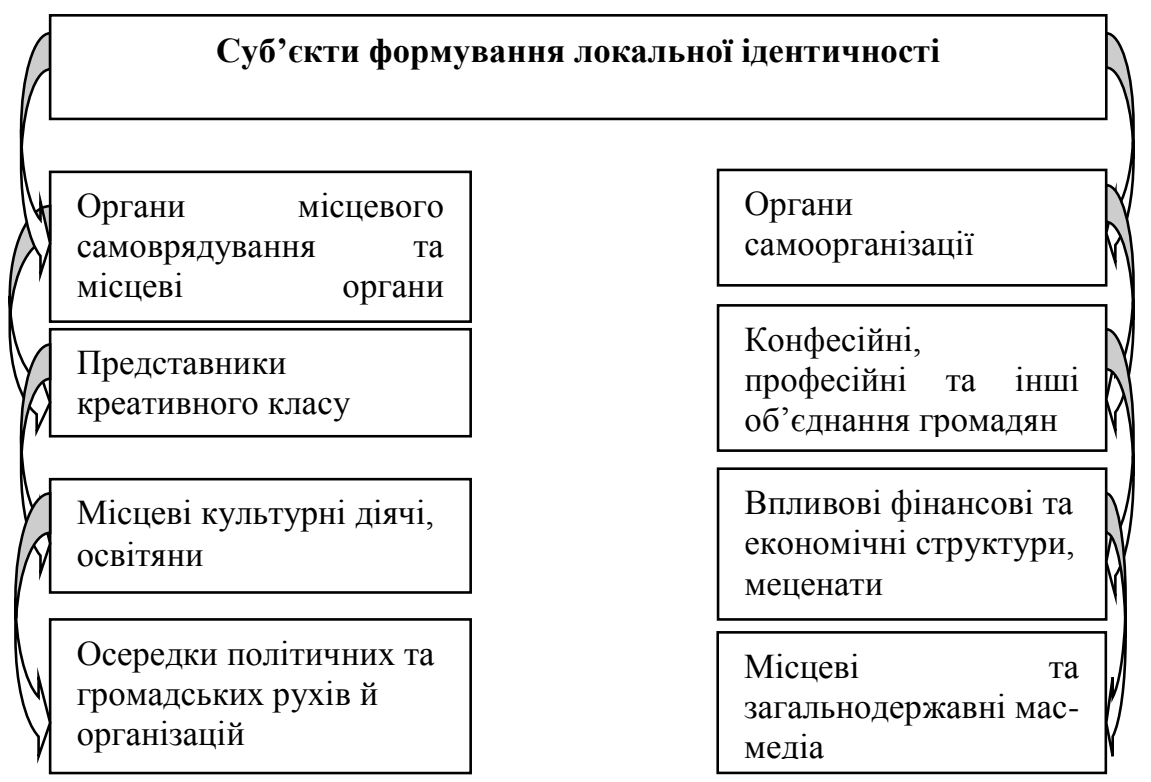

Рисунок 1 - Суб'єкти формування локальної ідентичності.

Складено на основі [2, с. $388 ; 8$, с. 33] 
Вважаємо за необхідне 3 метою розкриття обраної проблематики 3'ясувати: хто виступає суб'єктами локальної ідентичності, які функції вона виконує, на які види поділяється та яку структуру має на рівні ТГ. Суб'єкти формування локальної ідентичності зображено на рис. 1.

Функції локальної ідентичності полягають у:

сприянні серед членів місцевого співтовариства ТГ самодостатності, шляхом розвитку єдності, солідарності, довіри, поваги та взаєморозуміння;

активізації поведінкової активності місцевої спільноти;

підсиленні громадської ідентичності та консолідації членів місцевого співтовариства ТГ.

Також можна виділити два види локальної ідентичності. Перший - номінальний - індивід чи група індивідів виокремлюють себе із соціуму та починають ідентифікувати 3 певною спільнотою, яка проживає на території відповідної ТГ. Другий - реальний - індивід добровільно діє на користь своєї місцевої спільноти на основні прийнятих у неї інтересів та цінностей.

У формуванні локальної ідентичності ТГ можна виділити чотири основних компоненти:

1) локальний (територіальний) менталітет - властивий жителям певної місцевості, характерну для них систему цінностей і оцінок і т.п.;

2) уявлення про особливості й властивості території свого проживання;

3) територіальні інтереси - загальні для членів відповідної територіальної спільноти уявлення про стан, цілі і шляхи розвитку території;

4) локальна (просторова) самоідентифікація як усвідомлення приналежності до тієї території, територіальної спільності.

Структура локальної ідентифікації, завжди заснована на культурно-психологічній єдності населення, відчутті населенням ТГ своєї унікальності й презентації даної унікальності через формування локального іміджу.

Однак структура локальної самоідентифікації складніша, ніж нам iї пропонують дослідники. На нашу думку, структура 
локальної самоідентифікації практично завжди включає наступні складові: поведінковий, пізнавальний (когнітивний), емоційний, ціннісний, а в умовах децентралізації ще й інструментальний, що $є$ основою для соціальної й політичної мобілізації населення ТГ (рис. 2).

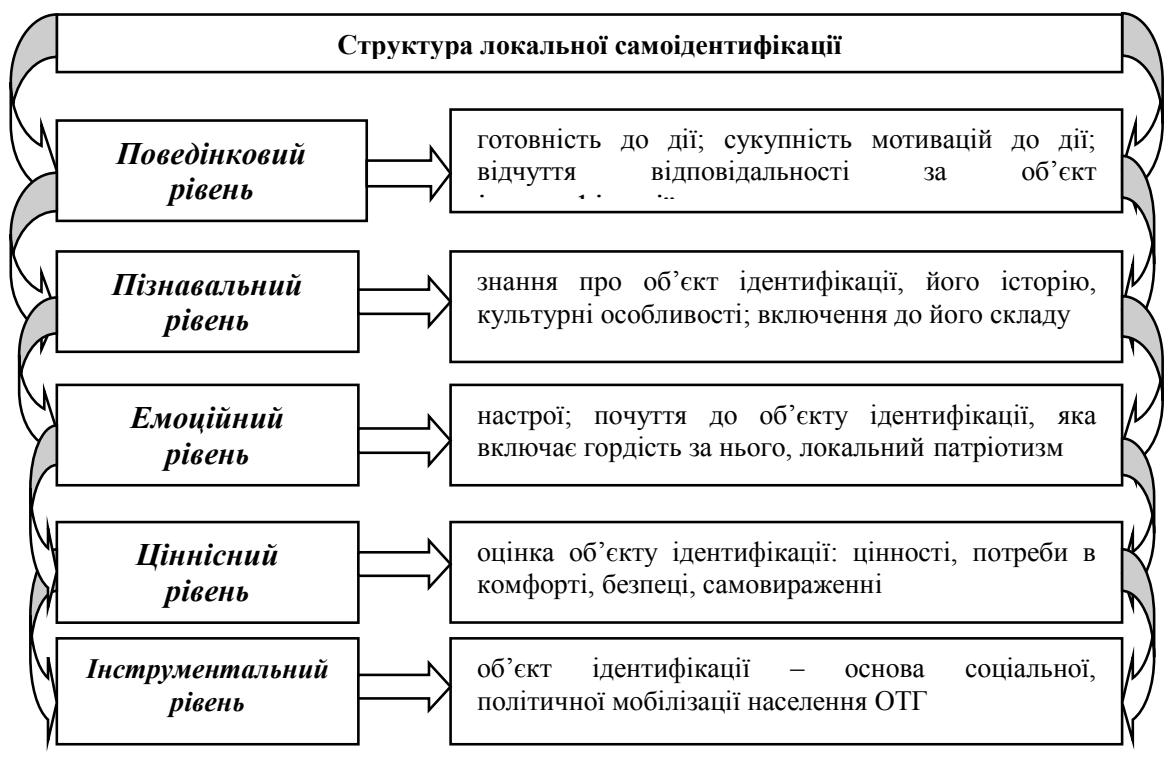

Рисунок 2 - Структура ідентичності

Складено автором на основі [2, с. $19 ; 8$, с. $8-9 ; 9$, с. 75].

В умовах децентралізації локальна ідентифікація $\epsilon$ суттєвою опорою для членів місцевого співтовариства ТГ, що дозволяє їм визначити власне становище, й стає підставою активності у вирішенні місцевих справ.

Аналіз автором ЗМI, матеріалів сайтів ТГ дозволяє охарактеризувати певний образ ТГ, як території, що складається в свідомості членів місцевого співтовариства. Саме тому досліджувати локальні ідентичності можна за допомогою соціологічних методів таких як опитування, анкетування, вивчення матеріальних артефактів, символічних індикаторів: історичні пам'ятки, місцева топоніміка, архітектура, а також за допомогою обробки статистичної інформації.

У Миколаївській області, станом на березень 2021 року 


\section{Науковий вісник : державне управління № 2(8) 2021}

існує 52 ТГ [10]. Кількість населення, охопленого децентралізацією (разом з Миколаєвом та містами обласного підпорядкування), сягає $90 \%$. Одним 3 найважливіших пріоритетів цього процесу є створення фінансово спроможних громад, що передбачає зосередження уваги не тільки на кількості створених ТГ, але й на їх якості [11, с. 36]. Більшість ТГ вже мають власні стратегії розвитку, тобто визначились зі своїм майбутнім. Так, основоположним документом, що передбачає формування спроможної ТГ є стратегія розвитку громад. Тобто, це перспективне бачення напрямів розвитку громади $з$ метою покращення іiі економічного, політичного, соціального клімату. Треба підкреслити, що до цього процесу залучаються жителі громади, структурні підрозділи відповідних рад, керівники підприємств, установ, організацій. Члени громад беруть участь в опитуваннях, які проводяться в процесі роботи над «Стратегією ТГ», у засіданнях групи зі стратегічного планування, залучаються до громадського обговорення проекту стратегії. Отже, наявність стратегії ТГ - це певний стримуючий фактор для їі розвитку. Наприклад в країнах Свропи навіть мова не йде про реалізацію будь-яких проектів громадами без наявності стратегії іï розвитку.

Але основна проблема створення стратегічного плану полягає в тому, що він має формуватися при активній участі членів ТГ. Саме завдяки локальній ідентичності може забезпечуватися активна участь громадян у прийнятті рішень місцевого значення. У той же час, як показує практика, активність мешканців у розробці стратегії громади доволі низька.

Автори дослідження [12, с. 165] зазначають, що локальна ідентичність «формує імідж громади, який вирізняє саме це місце i самих мешканців від інших подібних місць, та забезпечує іiі мешканцям почуття спокою, безпеки та гордості, поки вони живуть у цьому місці». Можна частково погодитися iз авторами, проте варто зазначити, що поняття локальної ідентичності, на нашу думку, включає не лише іміджеві показники, а й усвідомлення самими громадянами своєї значущості у формуванні спроможності ТГ. Пропонуємо розглянути складові локальної ідентичності, що безпосередньо 
впливають на стратегію розвитку ТГ (рис. 3).

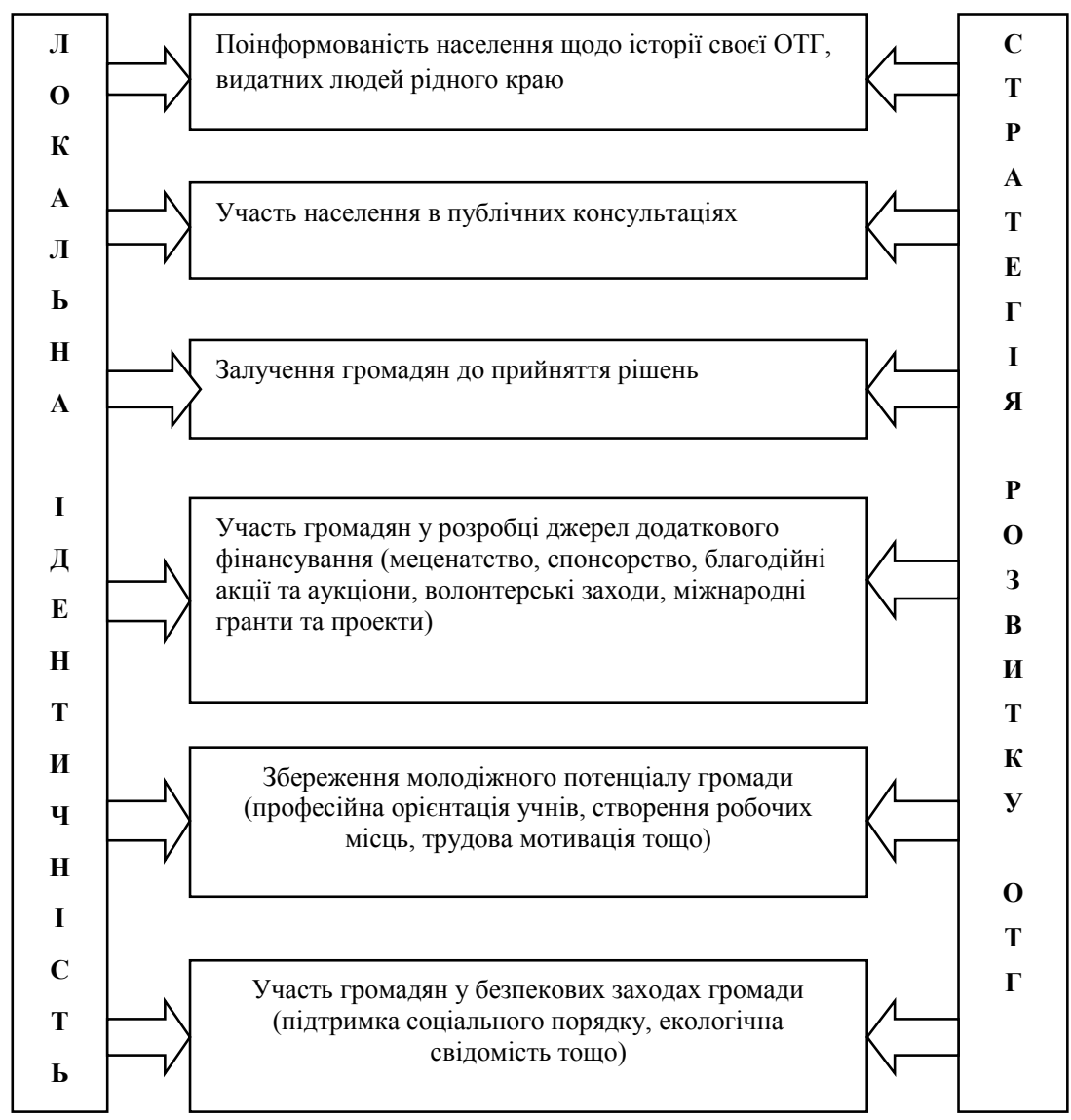

Рисунок 3 - Вплив локальної ідентичності та стратегії розвитку ТГ.

Складено автором

Тобто, Стратегія розвитку ТГ - це не просто документ, що має включати основні напрями розвитку економіки громади, а i перспективне бачення залучення громадян до управління громадою на основі партнерських відносин, соціального діалогу, що $\epsilon$ результатами культивування локальної ідентичності громадян.

Можна виділити три види спроможності під час створення ТГ: 
потенціальна (розрахункова) спроможність - передбачає фінансову здатність ТГ (що визначені такими згідно 3 перспективним планом) самостійно забезпечити належний рівень бюджетних послуг та інфраструктурного розвитку;

юридично визнана (правова) спроможність - закріплена у ст. 9 Закону України «Про добровільне об’єднання територіальних громад» та означає можливість самостійного застосування правових засобів вирішення конфліктних ситуацій членами ТГ [13];

реальна спроможність - виникає тоді, коли ТГ уже остаточно сформована і демонструє дійсні результати своєї діяльності.

Практика показує, що вищевказані види спроможності (потенціальна, юридично визнана, реальна) поєднуються, як правило, лише для тих ТГ, які утворюються навколо населених пунктів (районних центрів). У таких ТГ, зазвичай, до новостворених органів місцевого самоврядування (далі - ОМС) громади переходять співробітники районних державних адміністрацій і цим дещо вирішується проблема пов'язана 3 управлінськими кадрами на місцевому рівні [14].

У свою чергу створення сільських ТГ навколо населених пунктів, які не наділені статусом адміністративних центрів породжує проблему якісного кадрового забезпечення ОМС. Виникає потреба у кадрах, які б могли виконувати свої обов'язки за умов розширення повноважень ОМС і займатися вирішенням тих завдань, які раніше не були характерні для місцевого самоврядування.

Можна стверджувати, що фактично непередбачуваним процесом $\epsilon$ формування кадрових управлінських ресурсів у сільській місцевості, на відміну від обсягу фінансових ресурсів та стану об'єктів інфраструктури, які можна заздалегідь прорахувати. Сильна управлінська команда - це значна запорука успіху ТГ. Після об’єднання слід підтримувати належний якісний рівень і доступність публічних послуг, що надаються в ТГ і активно залучати громадян до прийняття рішень місцевого значення.

Так Баштанська міська ТГ була створена 09 вересня 2016 року, до іiі складу війшло 24 села. У рамках програми 


\section{Науковий вісник : державне управління № 2(8) 2021}

«Децентралізація приносить кращі результати та ефективність (DOBRE)», яка фінансується USAID розроблена «Стратегія розвитку ОТГ на 2018-2026 роки». Її аналіз показує, що складовою стратегії Баштанської ТГ $\epsilon$ сильна локальна ідентифікація, заснована на культурно-психологічній єдності населення, відчуття населенням ТГ своєї унікальності й презентація даної унікальності через стратегічний курс («Баштанська громада - унікальна за своєю історією, стабільна за своїм розвитком, ефективна за якістю життя своїх мешканців») [15].

Можна сказати, що стратегія розвитку Баштанської міської ТГ, що будується на локальній ідентичності має три компоненти: історичний (історичної спадщини території), культурно-ціннісний (ціннісні особливості місцевого співтовариства) i стратегічний (мається на увазі свідоме використання особливостей локальної ідентичності в практичних цілях, наприклад, для підвищення іміджу ТГ).

Громадами конкурентами для Баштанської міської ТГ $є$ Березнегуватська селищна ТГ й Новобузька міська ТГ (Табл.1).

Таблиия 1 - Порівняння Баштанської міської ТГ з громадамиконкурентами

\begin{tabular}{|l|c|c|c|}
\hline \multicolumn{1}{|c|}{ Показники } & $\begin{array}{c}\text { Баштанська } \\
\text { ТГ }\end{array}$ & $\begin{array}{c}\text { Березнегуватська } \\
\mathbf{T \Gamma}\end{array}$ & $\begin{array}{c}\text { Новобузька } \\
\text { ТГ }\end{array}$ \\
\hline Територія, кв.км & 1706,2 & 1263,7 & 1242,8 \\
\hline $\begin{array}{l}\text { Наявне населення (на } \\
01.01 .2020 \text { р.) тис.осіб }\end{array}$ & 36,5 & 19,3 & 29,9 \\
\hline $\begin{array}{l}\text { Зареєстровані безробітні } \\
\text { (31.12 2019 р.), осіб }\end{array}$ & 61 & 272 & 99 \\
\hline $\begin{array}{l}\text { Середня номінальна } \\
\text { заробітна плата (2019 р.), } \\
\text { грн }\end{array}$ & 7407 & 6595 & 6929 \\
\hline
\end{tabular}

Березнегуватська селищна ТГ утворилася у серпні 2018 року шляхом об'єднання однієї селищної та п'яти сільських рад (Березнегуватська селищна рада, Мурахівська, Новоукраїнська, Новоочаківська Білокриницька, Федорівська сільські ради). Стратегія розвитку Березнегуватської селищної ТГ, що будується на локальній ідентичності включає два 
компоненти: територіальні інтереси (збереження середовища ТГ, підвищення рівня комфортності та гарантування безпечного простору для відновлення інфраструктури); історична спадщина (імплементація стратегії розвитку ТГ 3 урахуванням i використанням позитивних надбань попереднього розвитку громади) [16].

Новобузька міська ТГ існує з 30 червня 2019 року та утворена шляхом об'єднання Новобузької міської та двох сільських рад (Новомихайлівської та Розанівської). Стратегія розвитку Новобузької міської ТГ заснована на таких компонентах локальної ідентичності: уявлення про особливості й властивості території свого проживання (цей компонент прослідковується, коли відбувається просторове планування процес урегулювання використання територій та формування необхідної земельної бази для того, щоб наміри визначені в стратегічному плані успішно реалізувалися); стратегічний (забезпечення сталого розвитку, який включає в себе економічний, суспільний та екологічно збалансований розвиток) [17].

Слід зазначити, що сильною стороною, яка надає перевагу у розвитку для Баштанської ТГ і Новобузької міської ТГ є вигідне географічне положення, у той час як для Березнегуватської селищної ТГ характерною є наявність ресурсів для стабільного розвитку сільськогосподарського виробництва. Спільним стратегічним компонентом локальної ідентичності та перспектив співпраці для всіх трьох громад є: 1) залучення фінансових ресурсів з метою ремонту дорожнього покриття на територіях ТГ; 2) організація підприємств 3 сортування та переробки сміттєвих відходів, що є загальною проблемою для всіх членів ТГ. Також важливим $є$ той факт, що стратегічний план розвитку вищевказаних ТГ формується за активної участі членів ТГ. Про це свідчить розробка та заповнення анкет для: 1) опитування бізнесу; 2) опитування мешканців; 3) залучення груп зі стратегічного планування до громадського обговорення проекту стратегій та їх подальшої реалізації.

У процесі децентралізації та створення спроможних ТГ на Миколаївщині відбувається об'єднання спільнот із своєю локальною ідентичністю, а отже із власними історичними, 


\section{Науковий вісник : державне управління № 2(8) 2021}

економіко-соціальними, конфесійними специфіками, що у майбутньому може призвести до виникнення конфліктних ситуацій чи конкуренції на фоні вказаних локальних ідентичностей, а це у свою чергу виступає стимулом соціальної напруженості та дезорганізації. Локальна ідентичність спроможної ТГ може бути сформована лише у випадку врахування цієї обставини керівництвом громади. Крім того, формування локальної ідентичності ТГ - це створення локального територіального простору, в якому місцеві мешканці існують, керуються певними традиціями й цінностями, мають власні символи, ознаки, уявлення що відрізняють їх від інших.

Стратегічне планування у розвитку ТГ повинне бути не лише інструментом економічно-соціальної ефективності та поліпшення життя громади, але i частиною політики формування локальної ідентичності, заснованої на принципах демократії, i повного урахування прав громадян [11]. Не зважаючи на те, що у процесі об'єднання громади отримують в першу чергу фінансові переваги, процес реалізації реформи $€$ таким, що створює значну кількість потенційних ризиків та загроз у сфері соціально-культурної політики та розвитку дійсно ефективного політичного плюралізму у громадах, а саме: невиконання поточних зобов'язань перед національними меншинами; нечіткий розподіл повноважень; «нехтування» законодавчими питаннями, що призводить до формування нової неповноцінної соціальної ідентичності.

Під час стратегічного планування розвитку ТГ керівництву слід зосередити увагу на ресурсах, які формують локальну ідентичність громади. Такі ресурси поділяються на:

особистісні: значимі особи (батьки, близькі родичі, друзі, колеги, земляки та ін.);

географічні: сукупність знань про локальну організацію територіального утворення та його природні особливості (кліматичні умови, рельєф, флора та фауна);

етнічні: самоідентифікація 3 етнічними групами, які населяють дану територію;

культурні: сукупність уявлень, пов'язаних із матеріальними та духовними цінностями, які створюються людьми у межах 
певної ТГ;

історичні: асоціативні уявлення, які пов'язані з історичним процесом розвитку місцевої спільноти.

Якщо таких ресурсів буде значна кількість, то можна говорити про створення спроможної ТГ.

Висновки та напрями подальших досліджень. Під час здійснення дослідження 3 обраної проблематики було сформовано авторське бачення поняття «локальна ідентичність». На думку автора статті локальна ідентичність це первинний, базовий рівень територіально-просторової ідентичності (ТГ), системна сукупність культурних, історичних, економічних, соціальних відносин, яка формується на основі місця проживання та $є$ фактором самоототожнення індивідів як членів місцевого співтовариства, яке проживає на території ТГ.

Отже, формування цілісної локальної ідентичності (як первинного рівня) є надзвичайно важливим етапом у розвитку регіональної, а згодом і національної ідентичності. Можна стверджувати, що наявність у ТГ позитивної локальної ідентичності виступає одним із головних факторів іiі суб'єктності та гарантією майбутнього сталого розвитку. Адже спроможна ТГ - це спільнота, яка ідентифікує себе з територією громади, відчуває причетність до подій, що відбуваються на іiі території, усвідомлює свої права та інтереси; узгоджує протилежні інтереси своїх членів; 3 ефективністю розпоряджається наявними ресурсами 3 метою місцевого розвитку, що обов'язково відображається при стратегічному плануванні й визначається в стратегії розвитку ТГ.

Сьогодні громади за своїми розмірами є досить великими територіальними утвореннями, в межах яких формується локальна ідентичність місцевих спільнот. Сформована локальна ідентичність дозволяє запланувати розвиток громади та покращення якості життя населення через систему соціальноекономічних показників, на довгостроковий період, що й стає змістом стратегії розвитку ТГ. Саме тому автор визначає формування локальної ідентичності - пріоритетним напрямом у стратегічному плануванні розвитку ТГ.

Подальшого дослідження в сучасних умовах потребує вивчення європейського досвіду ідентифікації місцевого 


\title{
Науковий вісник : державне управління № 2(8) 2021
}

\author{
населення в громаду в процесі децентралізації й залучення \\ місцевих жителів до розробки стратегії розвитку громади.
}

\section{Список використаних джерел}

1. Лола В. Локальна ідентичність та «соціальне включення» в умовах децентралізації влади в Україні. Аспекти публічного управління. Т. 8. № 1. 2020. С. 129-137

2. Котенко Я. В., Ткачук А. Ф. Локальна ідентичність і об'єднані територіальні громади. Вид. друге, випр. та доп. Київ: ТОВ «Видавництво «ЮСТОН», 2018. 56 с.

3. Євтушенко О., Лушагіна Т. Об'єднані територіальні громади Миколаївської області в умовах децентралізації: індикатори ефективності. Публічне управління та регіональний розвиток. Миколаїв, 2020. № 8. C. 396-421.

4. Свтушенко О. Н. Формування і конструювання локальної ідентичності територіальної спільноти в умовах децентралізації. Могилянські читання - 2020: досвід та тендениії розвитку суспільства в Україні: глобальний, національний та регіональний аспекти. XXIII Всеу. наук.-практ. конф. : тези доповідей Публічне управління в Україні в умовах децентралізації влади та наближення iіi до європейських стандартів, Миколаїв, 16-20 листопада 2020 р. / ЧНУ ім. Петра Могили. Миколаїв: Вид-во ЧНУ ім. Петра Могили, 2020. С. 1-3.

5. Овчиннікова Л. В. Місце та локальна спільнота як чинники формування локальної ідентичності. Вісник Харківського національного університету імені В. Н. Каразіна. Серія : Соціологічні дослідження сучасного суспільства: методологія, теорія, методи. 2012. № 999, Вип. 30. С. 137 142. URL: http://nbuv.gov.ua/UJRN/VKhISD 2012_999 30_26 (дата звернення 12.05.2021).

6. Erik H. Erikson. Identity, youth and crisis. New York: W. W. Norton Company, 1968. $300 \mathrm{p}$.

7. Jakaitis J., Stauskis G. Identification of local territorial communities in the urban structure of Vilnius city. The 8th International Conference. Vilnius, 2011. РP. 913-917.

8. Котенко Я. В. Локальна ідентичність як умова розвитку об'єднаних територіальних громад (навчальний модуль). Київ: ІКЦ «Легальний статус», 2016. 44 с.

9. Панченко Т. В. Регіональна і локальна ідентичності як складові культури субсидіарної демократії. Науковий часопис НПУ імені $M$. П. Драгоманова. Серія 22 : Політичні науки та методика викладання сочіально-політичних дисциплін. 2010. Вип. 4. С. 72-77. URL : http://nbuv.gov.ua/UJRN/Nchnpu_022_2010_4_15 (дата звернення 12.05.2021).

10. Громади. Миколаївська область. 2021 / Портал «Децентралізація» URL : https://decentralization.gov.ua/areas/0512/gromadu (дата звернення 12.05.2021).

11. Міняйло М. П. Особливості процесу децентралізації у Миколаївській області. Вісник аграрної науки Причорномор'я. 2019. Вип.1. С. 31-38.

12. Попова I. А., Демченко Н. В., Лебедин А. М. Моніторинг стратегій 


\section{Науковий вісник : державне управління № 2(8) 2021}

розвитку об'єднаних територіальних громад Харківської області в контексті використання інструментів ідентифікації. Modern Economics. 2020 . № $24 \quad$ (2020). $\quad$ C. $164-170 . \quad$ DOI: https://doi.org/10.31521/modecon.V24(2020)-26 (дата зверення 12.05.2021).

13. Про добровільне об'єднання територіальних громад: Закон України від 05.05.2018 № 157-VIII // База даних «Законодавство України»/ ВP України. URL : http://zakon.rada.gov.ua/laws/shOw/157-19 (дата звернення 12.05.2021).

14. Балдич Н. Дослідження навчальних потреб представників органів місцевого самоврядування України. Аналітичний звіт. URL : https://cutt.ly/Nnffohh (дата звернення 12.05.2021).

15. Стратегічний план розвитку Баштанської міської ради Миколаївської області на 2018-2025 роки (Баштанської об'єднаної територіальної громади). Вебпортал URL : https://cutt.ly/fnff7S1 (дата звернення 12.05.2021).

16. Стратегії розвитку Березнегуватської об'єднаної територіально громади. URL: https://cutt.ly/hnfgqI3 (дата звернення 12.05.2021).

17. Розробка стратегії розвитку Новобузької територіальної громади на 2021-2027 роки. Вебпортал. URL: https://cutt.ly/6nfgtW6 (дата звернення 12.05.2021).

\section{References}

1. Lola, V. (2020) Lokalna identychnist ta «sotsialne vkliuchennia»v umovakh detsentralizatsii vlady v Ukraini [Local identity and "social inclusion" in the context of decentralization of power in Ukraine]. Aspekty publichnoho upravlinnia - Aspects of public administration. T. 8. № 1. S. 129-137 [in Ukrainian].

2. Kotenko, Ya. V., Tkachuk, A. F. (2018) Lokalna identychnist i obiednani terytorialni hromady (vydannia druhe, vypravlene ta dopovnene) [Local identity and united territorial communities]. Kyiv: TOV «Vydavnytstvo «IuSTON». 56 s. [in Ukrainian].

3. Ievtushenko, O. N. Obiednani terytorialni hromady Mykolaivskoi oblasti v umovakh detsentralizatsii: indykatory efektyvnosti [United territorial communities of Mykolayiv region in the conditions of decentralization: efficiency indicators]. Publichne upravlinnia ta rehionalnyi rozvytok - Public Administration and Regional Development. - Mykolaiv, 2020. № 8. S. 396421 [in Ukrainian].

4. Ievtushenko, O. N. (2020) Formuvannia i konstruiuvannia lokalnoi identychnosti terytorialnoi spilnoty v umovakh detsentralizatsii [Formation and construction of the local identity of the territorial community in the conditions of decentralization]. Mohylianski chytannia - 2020: dosvid ta tendentsii rozvytku suspilstva v Ukraini: hlobalnyi, natsionalnyi ta rehionalnyi aspekty. KhKhIII Vseu. nauk.-prakt. konf. : tezy dopovidei Publichne upravlinnia v Ukraini $v$ umovakh detsentralizatsii vlady ta nablyzhennia yii do yevropeiskykh standartiv, Mykolaiv, 16-20 lystopada 2020 r. / ChNU im. Petra Mohyly. Mykolaiv: Vyd-vo ChNU im. Petra Mohyly, 2020. S. 1-3. [in Ukrainian].

5. Ovchynnikova, L. V. (2012) Mistse ta lokalna spilnota yak chynnyky formuvannia lokalnoi identychnosti [Place and local community as factors of 


\section{Науковий вісник : державне управління № 2(8) 2021}

local identity formation]. Visnyk Kharkivskoho natsionalnoho universytetu imeni V. N. Karazina. - Specialized journal V. N. Karazin Kharkiv National University Bulletin. Seriia : Sotsiolohichni doslidzhennia suchasnoho suspilstva: metodolohiia, teoriia, metody. № 999, Vyp. 30. S. 137-142. Retrieved from http://nbuv.gov.ua/UJRN/VKhISD_2012_999 30_26 [in Ukrainian].

6. Erik, H. Erikson (1968) Identity, youth and crisis. New York: W. W. Norton Company, 1968. 300 p. [in English].

7. Jakaitis, J., Stauskis, G. (2011) Identification of local territorial communities in the urban structure of Vilnius city. The 8th International Conference. Vilnius. PP. 913-917 [in English].

8. Kotenko, Ya. V. (2016) Lokalna identychnist yak umova rozvytku obiednanykh terytorialnykh hromad (navchalnyi modul) [Local identity as a condition for the development of united territorial communities (training module)]. Kyiv: IKTs «Lehalnyi status», 2016. 44 s. [in Ukrainian].

9. Panchenko, T. V. (2010) Rehionalna i lokalna identychnosti yak skladovi kultury subsydiarnoi demokratii [Regional and local identities as components of the culture of subsidiary democracy.]. Naukovyi chasopys NPU imeni M. P. Drahomanova. - Scientific journal of National Pedagogical Dragomanov University. Seriia 22 : Politychni nauky ta metodykavykladannia sotsialnopolitychnykh dystsyplin. Vyp. 4. S. 72-77. Retrieved from http://nbuv.gov.ua/UJRN/Nchnpu_022_2010_4_15 [in Ukrainian].

10. Hromady. Mykolaivska oblast (2021). Retrieved from https : //decentralization.gov.ua/areas/0512/gromadu [in Ukrainian].

11. Miniailo, M. P. (2019) Osoblyvosti protsesu detsentralizatsii u Mykolaivskii oblasti [Features of the decentralization process in the Mykolaiv area]. Visnyk ahrarnoi nauky Prychornomoria - Bulletin of Agrarian Science of the Black Sea Coast. Vyp. 1. S.31-38 [in Ukrainian].

12. Popova, I. A., Demchenko, N. V., Lebedyn, A. M. (2020) Monitorynh stratehii rozvytku obiednanykh terytorialnykh hromad Kharkivskoi oblasti $\mathrm{v}$ konteksti vykorystannia instrumentiv identyfikatsii [Monitoring of development strategies of united territorial communities of Kharkiv region in the context of using identification tools]. Modern Economics. № 24(2020). S. 164-170. DOI: https://doi.org/10.31521/modecon.V24(2020)-26 [in Ukrainian].

13. Pro dobrovilne obiednannia terytorialnykh hromad: Zakon Ukrainy vid 05.05.2018 № 157-VIII. [On voluntary association of territorial communities: Law of Ukraine of 05.05.2018 № 157-VIII]. Retrieved from http://zakon.rada.gov.ua/laws/shOw/157-19 [in Ukrainian].

14. Baldych, N. Doslidzhennia navchalnykh potreb predstavnykiv orhaniv mistsevoho samovriaduvannia Ukrainy. Analitychnyi zvit [The study of educational needs of local self-government bodies representatives of Ukraine. Analytical report]. Retrieved from http://www.slg-coe.org.ua/wpcontent/uploads/2019/07/TNA_Ukraine-2018-2019-Final-Report_ukr_F.pdf [in Ukrainian].

15. Stratehichnyi plan rozvytku Bashtanskoi miskoi rady Mykolaivskoi oblasti na 2018-2025 roky (Bashtanskoi obiednanoi terytorialnoi hromady) [Strategic plan of development of the Bashtanska city council of the Mykolaiv area for 2018-2025 (Bashtanska united territorial community)]. Retrieved from https://cutt.ly/JnfgpLo [in Ukrainian]. 
16. Stratehii rozvytku Bereznehuvatskoi obiednanoi terytorialno hromady [Development strategies of Bereznehuvatska united territorial community]. URL: https://cutt.ly/vnfgfp5 [in Ukrainian].

17. Rozrobka stratehii rozvytku Novobuzkoi terytorialnoi hromady na 2021-2027 roky [Development strategy of the Novobuzhskaya territorial community for 2021-2027]. Retrieved from https://cutt.ly/5nfgjyh [in Ukrainian].

\title{
LOCAL IDENTITY AS A PRIORITY DIRECTION IN STRATEGIC PLANNING OF TERRITORIAL COMMUNITIES DEVELOPMENT
}

\section{Suslov Mykola}

\begin{abstract}
The author of the article investigated local identity as a priority direction in the strategic planning of territorial communities (TC) at the present stage. Local identity is the identification of oneself with the society that lives in a given territory, in particular, in the territory of the TC. In the context of decentralization, local identification is an essential support for members of the TC local community, which allows them to determine their own position, and becomes the basis for activity in solving local affairs. In the formation of the local identity of the TC, the author has identified four main components: 1) local (territorial) mentality - characteristic of residents of a certain area, their characteristic system of values and assessments; 2) an idea of the features and properties of the territory of their residence; 3) territorial interests - a common idea for members of the respective territorial community about the state, goals and ways of the territory development; 4) local (spatial) self-identification as an awareness of belonging to that territory, territorial community. One of the most important priorities of the decentralization process is the creation of financially wealthy communities, which involves focusing not only on the number of TC created, but also on their quality. The author has proved that the fundamental document that provides for the formation of a capable $\mathrm{TC}$ is a community development strategy. It was found that the main problem of creating a strategic plan is that it should be formed with the active participation of TC members. It's thanks to local identity that the active participation of citizens in decision-making of local significance can be ensured. In the article, the author comes to the conclusion that strategic planning in the development of TC shouldn't only be an instrument of economic and social efficiency and improve the life of society, but also a part of the policy of forming local identity based on the principles of democracy and full consideration of citizens' rights.
\end{abstract}

Key words: local identity, decentralization, efficiency, strategic planning of territorial communities. 